\title{
MORPHODYNAMICS OF A CARIBBEAN BEACH FRINGED BY A CORAL REEF
}

\author{
Amaia Ruiz de Alegria-Arzaburu ${ }^{1}$, Ismael Mariño-Tapia ${ }^{2}$, Cecilia Enriquez $^{3}$, \\ Rodolfo Silva-Casarín ${ }^{3}$, Mariana González-Leija ${ }^{2}$ \\ ${ }^{1}$ Instituto de Investigaciones Oceanológicas, Universidad Autónoma de Baja California (UABC), km 103 Carretera \\ Tijuana-Ensenada, 22860, Ensenada, México. Corresponding author: amaia@uabc.edu.mx \\ ${ }^{2}$ Centro de Investigación y Estudios Avanzados (CINVESTAV), Unidad Mérida del Instituto Politécnico Nacional, \\ km.6 antigua Carretera Progreso-Cordemex, 097310, Mérida, México \\ ${ }^{3}$ Instituto de Ingeniería, Universidad Nacional Autónoma de México (UNAM), Cd. Universitaria, 04360, México
}

\begin{abstract}
The morphological response of two adjacent beaches, on the Mexican Caribbean coast, exposed to the same offshore wave climate is compared, where one of the beaches is fringed by a coral reef and the other is not. Detailed topographic and bathymetric measurements were collected from 2007 to 2011 using a differential GPS and doublefrequency echo-sounder. Offshore waves were continuously measured by the NOAA 42056 directional buoy, and nearshore waves were measured from May to September 2007 using an acoustic wave and current profiler to validate the use of offshore waves in the analysis of beach morphodynamics. Investigations showed that the beach with the fringing coral reef was the more stable under the same offshore energetic wave conditions of different directions. The implications of the fringing reef on the local hydrodynamics and energy dissipation were evaluated with the SWAN third-generation spectral wave model. The model was first validated with wave measurements collected at intermediate (forereef) and shallow waters (reef lagoon) with Aquadop profilers. Numerical results indicate that during shore-normal energetic conditions, the fringing reef is capable of reducing the incoming wave energy by up to $65 \%$.
\end{abstract}

Keywords: beach morphodynamics; fringing coral reef; wave energy dissipation.

\section{INTRODUCTION}

There is increasing interest in understanding the long-term stability of coasts under energetic wave conditions and accounting for rising sea levels. Coral reefs are abundant in shallow tropical and subtropical coastal regions, providing environments where a considerable amount of wave energy can be dissipated through bottom friction and wave breaking processes (Lowe et al., 2005). Many coral reefs, however, are presently in gradual decline (Gardner et al., 2003) and fringing reefs especially are sensitive to rising water levels, which are expected to outstrip any potential reef flat accretion (Storlazzi et al., 2011).

The efficiency of coral reefs in dissipating incident wave energy, either through the friction exerted by bottom roughness, or simply as obstacles to wave action, makes them excellent natural coastal defences (Hearn, 1999; Sheppard et al., 2005; Zawada et al. 2010; Alvarez-Filip et al. 2011). Hydrodynamic investigations on coral reefs have focused on understanding the relationship between the transformation of incident waves, and the topography of reef platforms. Moreover, wave breaking, wave set-up and wave-induced flows can control the circulation on fringing reef lagoons (Coronado,et al., 2007). The arrival of residual wave energy to the shore can, however, cause significant morphological changes.

Since the early 1970's most coral reefs in the shallow Caribbean Sea have been reported in decay due to loss of complexity (Alvarez-Filip et al. 2009). Present coastlines protected by these decaying coral reefs are expected to be gradually exposed to greater wave energy due to the decreased capability of the reef to attenuate wave energy. Consequently, adverse morphological variations along the shores and the beaches fronting these reefs can be expected (Sanderson, 2000; Sheppard et al., 2005).

At present, however, the morphodynamics of beaches fringed by coral reefs has received little attention. Only a few studies have quantified the morphological differences in reef-protected coastlines in relation to the incident wave energy (Sanderson 2000; Kench et al. 2009). This investigation aims to provide, for the first time, an understanding of the morphodynamic differences of a reef fronted beach compared to an adjacent beach without a reef. In addition, the degree of total energy dissipation provided by the fringing reef is quantified and related to the morphological change along the beach. 


\section{FIELD SITE}

The field sites are the microtidal beaches of Cancun and Puerto Morelos, located on the Mexican Caribbean coast (Fig. 1). Semi-diurnal tidal oscillations in the study area are small, and the mean tidal range is $\sim 0.17 \mathrm{~m}$. The dominant waves approach from east/southeast, are of low energy (significant wave height, $\mathrm{H}_{\mathrm{s}}=0.5-1.5 \mathrm{~m}$ ) and short period (mean wave period, $\mathrm{T}_{\mathrm{m}}=4-6 \mathrm{~s}$ ), and dominate from May to October. During these months, the incidence of hurricanes is common $\left(\mathrm{H}_{\mathrm{s}}=6-12 \mathrm{~m} ; \mathrm{T}_{\mathrm{m}}=10\right.$ 12). Northerly energetic waves $\left(H_{s}=2-3 \mathrm{~m}\right)$ of longer period $\left(T_{m}=6-8 \mathrm{~s}\right)$ occur frequently from November to April.

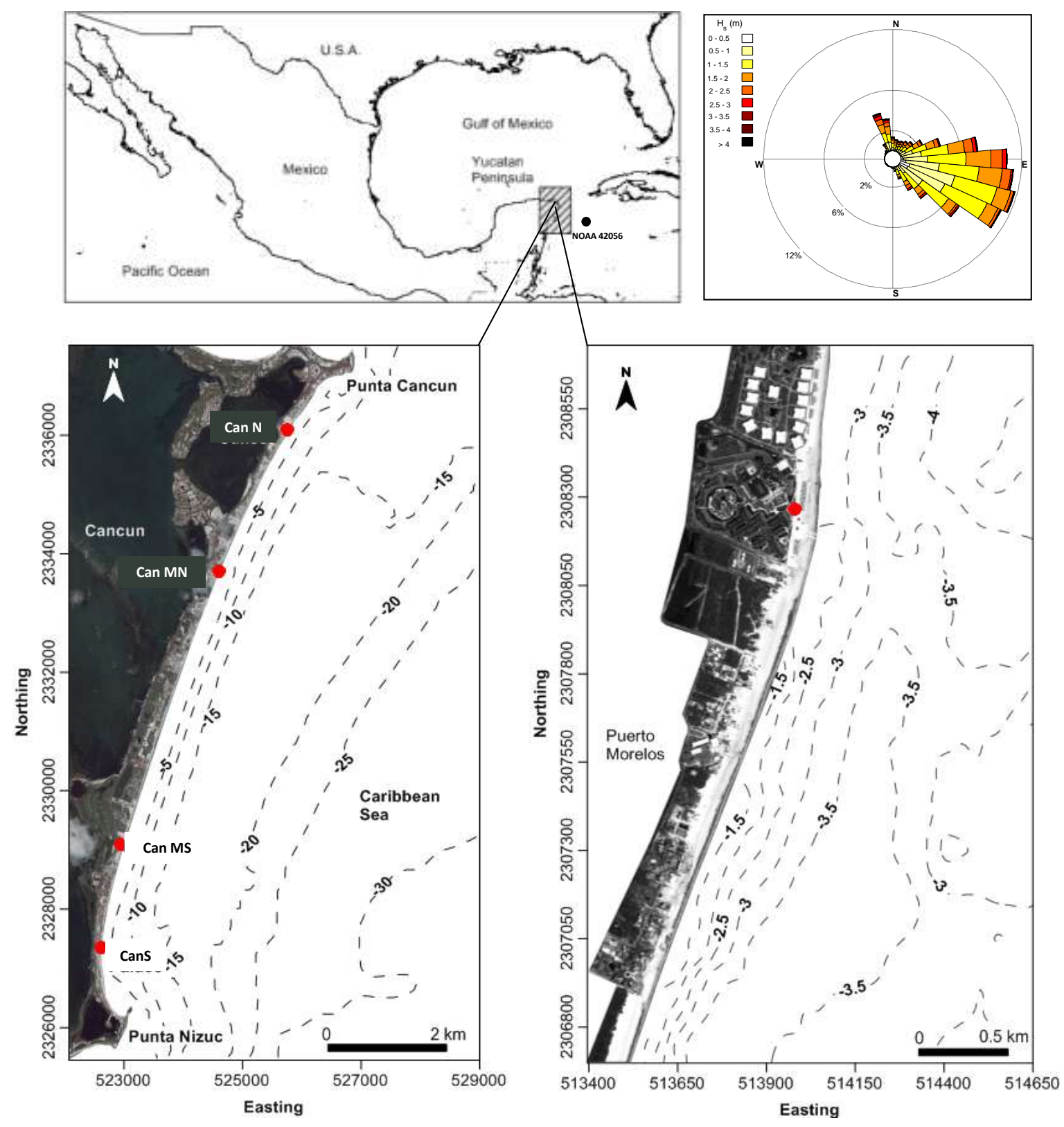

Figure 1. Location and bathymetric information of the studied beaches at Cancun (left) and Puerto Morelos (right) on the Mexican Caribbean coast. The red dots in the bottom panels indicate the middle location of each beach section (Can N, MN, MS, S, and Puerto Morelos). The wave rose presents offshore data measured in deep water by the NOAA 42056 directional buoy (see location with black dot on top left panel) over a 4 year period from September 2007 to May 2011. 
The beaches of Cancun and Puerto Morelos are composed of carbonate medium sand of biogenic origin, and the mean sediment sizes are $\sim 0.4$ and $\sim 0.3 \mathrm{~mm}$, respectively. The beach of Puerto Morelos is fronted by a fringing reef which extends $4 \mathrm{~km}$ alongshore and creates a $\sim 2 \mathrm{~km}$ wide shallow reef lagoon of 3 to $4 \mathrm{~m}$ depth. Some of the reef crests are exposed at low-spring tide. Cancun beach $(\sim 20 \mathrm{~km}$ north) has no fronting reef. It is a barrier beach backed by a shallow lagoon, permanently connected to the Caribbean Sea via two inlets, and the beach is enclosed by two rocky foreshores.

\section{METHODS}

\section{Field measurements}

Five $\sim 2 \mathrm{~km}$ long beach sections were monitored from September 2007 to May 2011 along the two microtidal beaches of Puerto Morelos, fringed by a reef, and Cancun, without a reef (see Fig. 1), both being exposed to the same offshore wave conditions. Morphological data consisted of three-to-four monthly measurements of beach topography using a differential Global Positioning System (GPS). Beach profiles were measured every $20 \mathrm{~m}$ alongshore, and these were linearly interpolated over the beach section and a three-dimensional digital elevation model was obtained.

Bathymetric data were collected almost annually using a double-frequency echo-sounder. Figure 2 presents the bathymetry of the research site, and evidences the underlying differences of the two beaches of interest. In Cancun the bathymetry gradually decreased to $20 \mathrm{~m}$ depth at an offshore distance of $\sim 2 \mathrm{~km}$ (see A in Fig. 2). Whereas at the same offshore distance Puerto Morelos presented a shallow reef lagoon, reef crest and a sudden deepening to $20 \mathrm{~m}$ in the forereef (see B in Fig. 2).

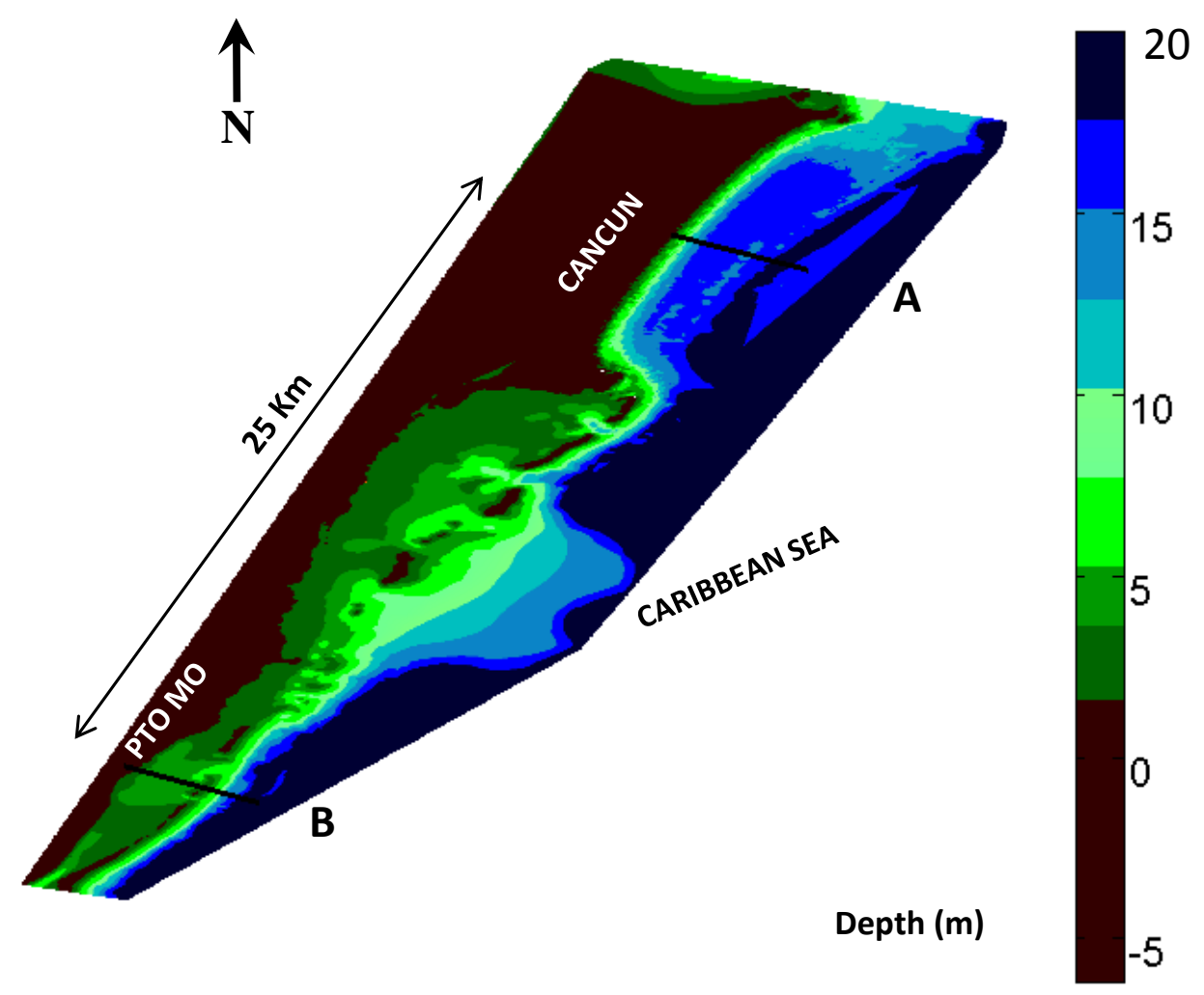

Figure 2. Bathymetry of the research site comprising the area between the beaches of Cancun and Puerto Morelos. The lines in A and B represent a cross-shore distance of $\sim 2 \mathrm{~km}$ for both beaches.

Nearshore wave measurements were collected with an acoustic wave and current profiler (AWAC) at $20 \mathrm{~m}$ depth at $B$ (Fig. 2) from May to September 2007. The comparison of the nearshore measurements with the NOAA 42056 deep water directional wave data (http://www.ndbc.noaa.gov) indicated an acceptable agreement between both datasets except during hurricanes, and maximum differences of $\pm 0.5 \mathrm{~m}$ and $2-3 \mathrm{~s}$ were observed for $\mathrm{H}_{\mathrm{s}}$ and $\mathrm{T}_{\mathrm{m}}$, respectively. Thus, the changes in beach 
topographies were related to the offshore wave measurements such as wave heights $\left(\mathrm{H}_{\mathrm{s}}\right)$, periods and wave directions obtained from the NOAA buoy.

\section{Wave modelling}

The SWAN (Simulating Waves in the Near-shore) third-generation phase averaged wind wave model (Booij et al., 1999) was employed to propagate waves from deep to shallow water depths and allow the evaluation of the degree of total energy dissipation provided by the fringing reef. The model was set-up using field measured subtidal morphology and combined with freely available ETOPO1 data of 1 minute resolution (http://www.ngdc.noaa.gov), and a rectangular model grid of $125 \mathrm{~m}$ resolution was established. SWAN is based on discrete spectral action balance equations which compute the evolution of random short-crested waves. Earlier researchers have found this model capable of accurately modelling the propagation and breaking of waves over coral reefs (e.g. Lowe et al., 2009; Hoeke et al., 2011; Storlazzi et al., 2011).

Previous studies indicated the need for bottom roughness values of an order of magnitude greater than for sand, and based on Madsen et al. [1988] wave hydraulic roughness lengths $\left(\mathrm{k}_{\mathrm{w}}\right)$ of $0.1-0.2 \mathrm{~m}$ were suggested for coral reefs [Hearn, 1999; Lowe et al., 2005; Hoeke et al., 2011]. In order to determine the use of the optimal $\mathrm{k}_{\mathrm{w}}$ value for this study, the model was calibrated with wave measurements collected at intermediate $(\sim 15 \mathrm{~m}$ off the reef crest) and shallow waters $(\sim 3 \mathrm{~m}$ within the reef lagoon) using Aquadop acoustic profilers (within line B in Fig. 2). Model calibration results indicated that the use of a spatially uniform $\mathrm{k}_{\mathrm{w}}$ value of $0.1 \mathrm{~m}$ provided acceptable errors with $\mathrm{R}^{2}=0.64$ (Fig. 3). Within SWAN, the Battjes and Stive [1985] model was used to determine the depth-induced breaking with the constants of $\alpha=1$ and $\gamma=0.73$.

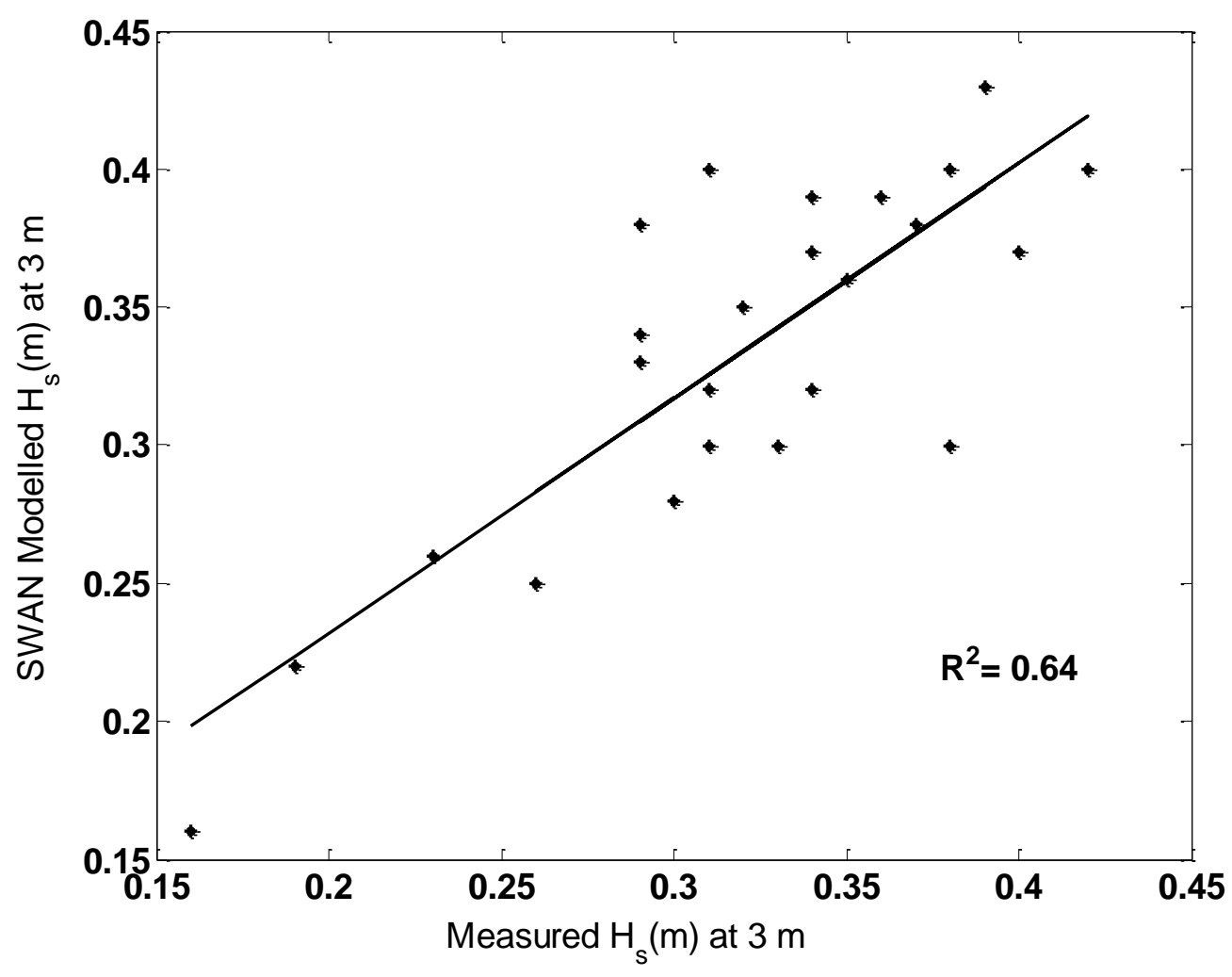

Figure 3. Comparison of measured and modelled significant wave heights at shallow waters ( $3 \mathrm{~m}$ in the reef lagoon) using a spatially uniform wave hydraulic roughness length $\left(k_{w}\right)$ value of $0.1 \mathrm{~m}$. 


\section{RESULTS}

\section{Morphological change}

The morphological variability of each beach section was quantified in terms of volumetric change $(\Delta \mathrm{V})$ at alongshore cells of $10 \mathrm{~m}$, for concurrent beach profiles using wave measurements from September 2007 to May 2011. The dominant waves in the field site approached either from the northnorthwest (N/NW) or east-southeast (E/SE), thus, the volumetric change along each beach section was determined during periods of these dominant wave conditions. Results presented in Figure 4 indicate that under shore-normal E/SE waves, the beach section in Puerto Morelos was significantly less dynamic than the rest of the beach sections in Cancun (Can N, MN, MS and S), whereas during N/NW wave conditions the magnitude of volumetric change was similar for both sites. During the shorenormal E/SE waves, alongshore averaged volumetric differences $(\Delta \mathrm{V}) \pm 5 \mathrm{~m}^{3} / \mathrm{m}$ were measured in Puerto Morelos, whereas in Cancun the volumetric change was generally greater $\Delta \mathrm{V} \pm 10 \mathrm{~m}^{3} / \mathrm{m}$. The most dynamic section on Cancun beach was Can MS, where average volumetric changes of $\sim 15 \mathrm{~m}^{3} / \mathrm{m}$ were registered.

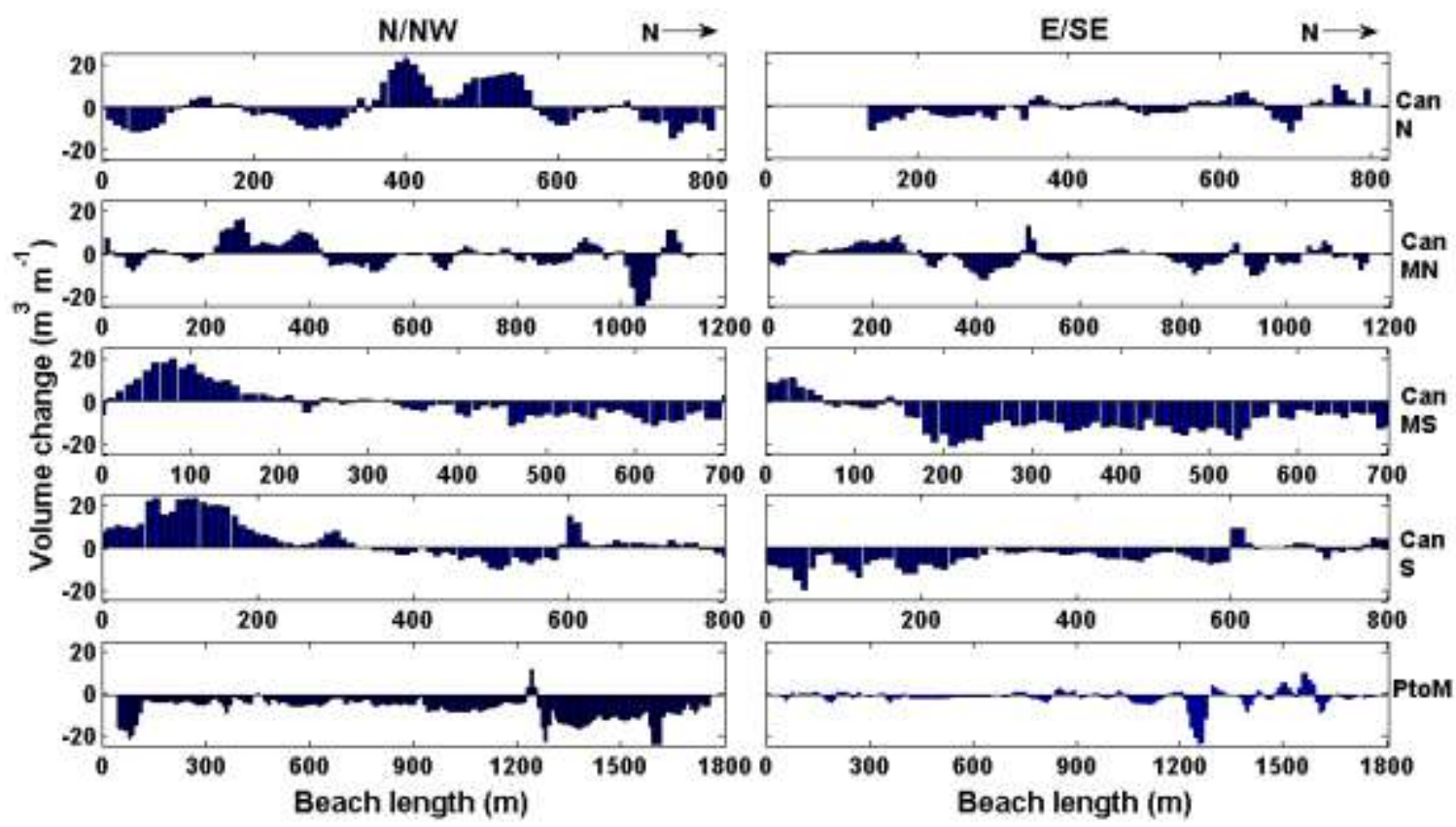

Figure 4. Volumetric change along each beach section (Can N, MN, MS, S and PtoM) calculated from the measured beach profiles before and after a period of dominant N/NW waves (left) and E/SE waves (right).

\section{Wave propagation}

Extreme wave conditions of $\mathrm{H}_{\mathrm{s}}=3 \mathrm{~m}$ and $\mathrm{T}=7 \mathrm{~s}$ were propagated with the calibrated SWAN model over the study area for dominant northerly and easterly wave conditions with the aim of evaluating the amount of wave energy dissipation (in terms of $\left.\mathrm{H}_{\mathrm{s}}\right)$, from intermediate $(\sim 12 \mathrm{~m})$ to shallow $(\sim 3 \mathrm{~m})$ waters (Figs. 5 and 6 ). The simulations were computed in stationary mode for a constant tidal level of 0 $\mathrm{m}$ and the wind was not considered. 


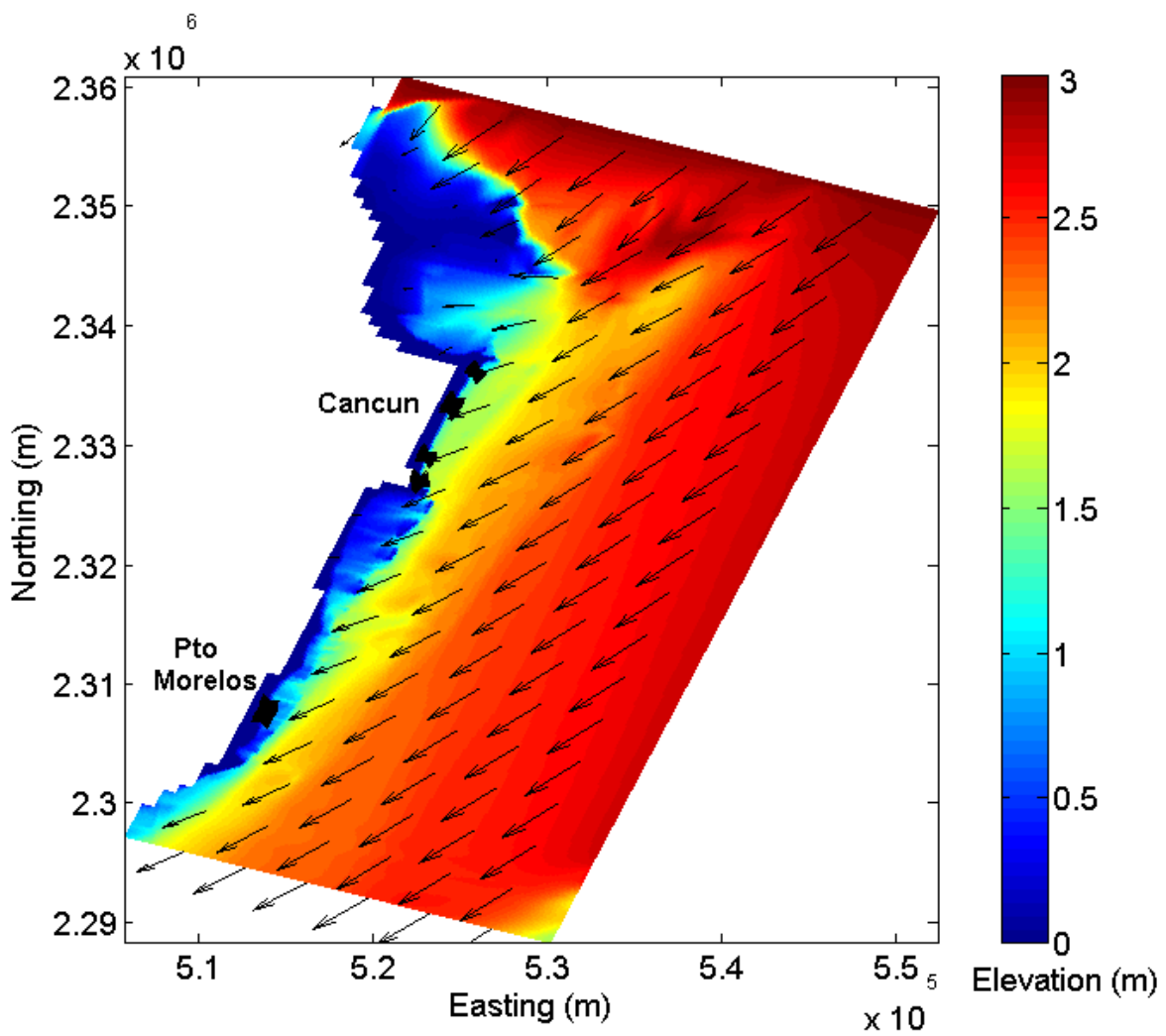

Figure 5. An example of a SWAN wave simulation (magnitude and direction) over the study area for northeasterly $\mathrm{H}_{\mathrm{s}}=\mathbf{3} \mathrm{m}$ and $\mathrm{T}=7 \mathrm{~s}$ waves. The beach sections in Cancun and Puerto Morelos are shown in black.

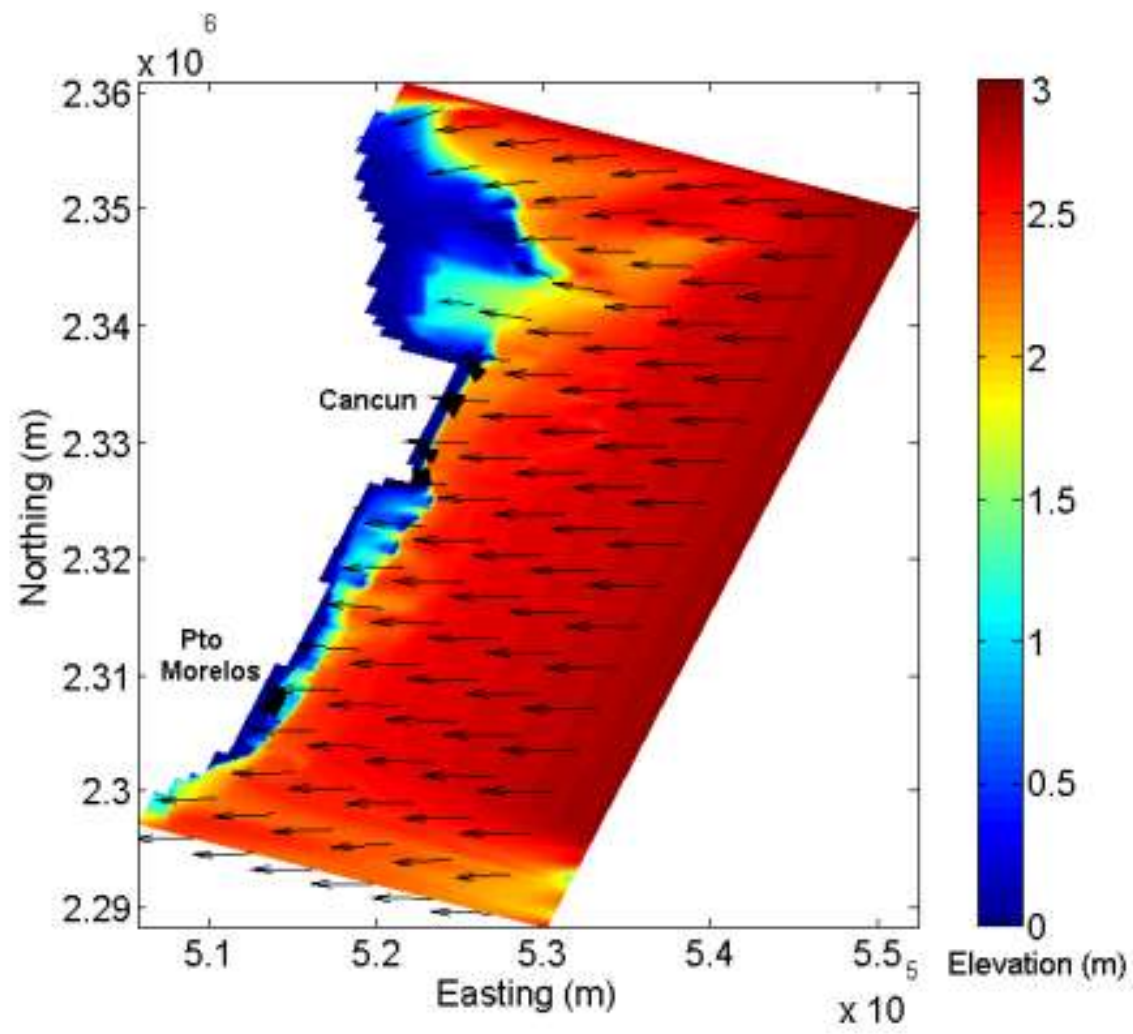

Figure 6. An example of a SWAN wave simulation (magnitude and direction) over the study area for easterly $H_{s}=3 \mathrm{~m}$ and $\mathrm{T}=7 \mathrm{~s}$ waves. The beach sections in Cancun and Puerto Morelos are shown in black. 
SWAN wave modelling results showed a significant reduction in the incident wave energy for Puerto Morelos compared to Cancun (Fig. 7). Reductions in wave height of up to $1.5 \mathrm{~m}$ were observed close to the shore in Puerto Morelos, whereas Cancun barely attenuated wave energy for the dominant E waves. The significant wave height reductions at Cancun could be considered a direct consequence of the shoaling effects, whereas at Puerto Morelos the wave energy attenuation is primarily attributed to the presence of the fringing reef at a distance of 500 to $1,500 \mathrm{~m}$ off the coast.
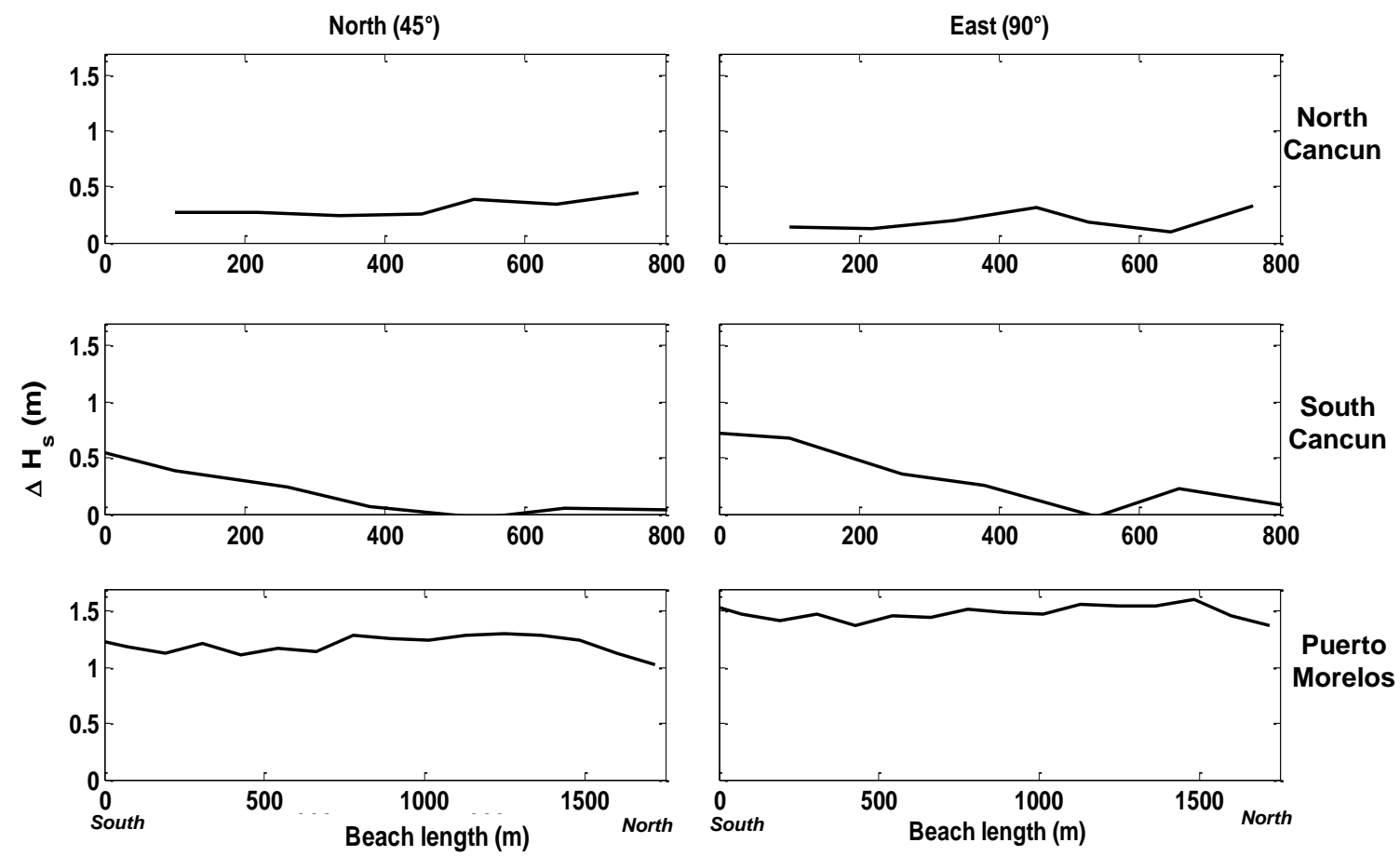

Figure 7. Differences in significant wave height between intermediate (12 $\mathrm{m})$ and shallow (3 $\mathrm{m})$ waters derived from the SWAN outputs along the studied beach sections for the main wave directions. Boundary conditions for northerly (left) and easterly (right) $\mathrm{H}_{\mathrm{s}}=3 \mathrm{~m}$ and $\mathrm{T}=7 \mathrm{~s}$ waves.

\section{DISCUSSION}

The morphological data confirmed that the beach of Puerto Morelos is wider and generally more stable than Cancun. The volumetric differences $(\Delta \mathrm{V})$ along each beach section indicated that during E/SE wave conditions the beach of Puerto Morelos was significantly more stable than Cancun. On the other hand, during N/NW waves the volumetric changes at both beaches were of the same order of magnitude (Fig. 4). The morphological change along each beach section was related to the amount of wave energy dissipation, which was determined as the percentage of significant wave height reduction from intermediate $(\sim 12 \mathrm{~m})$ to shallow $(\sim 3 \mathrm{~m})$ waters.

Figure 8 presents the comparison of the volumetric change along the beach and the percentage of significant wave height reduction at Puerto Morelos, and Cancun MS, the most dynamic beach section in Cancun. For dominant easterly (E) waves, SWAN wave modelling results showed up to $65 \%$ reduction in the incident wave energy $\left(\sim \mathrm{H}_{\mathrm{s}}\right)$ from intermediate to shallow waters for Puerto Morelos, compared to $25 \%$ in Cancun. During northwesterly (NW) waves smaller reductions of $\sim 40 \%$ and $\sim 15 \%$ were observed, respectively (Fig. 8). Thus, the larger energy dissipation and volumetric stability during E waves in Puerto Morelos compared to Cancun is attributed to the presence of the fringing reef off Puerto Morelos. In contrast, the wave energy dissipation in Cancun is assigned to wave shoaling effects. 

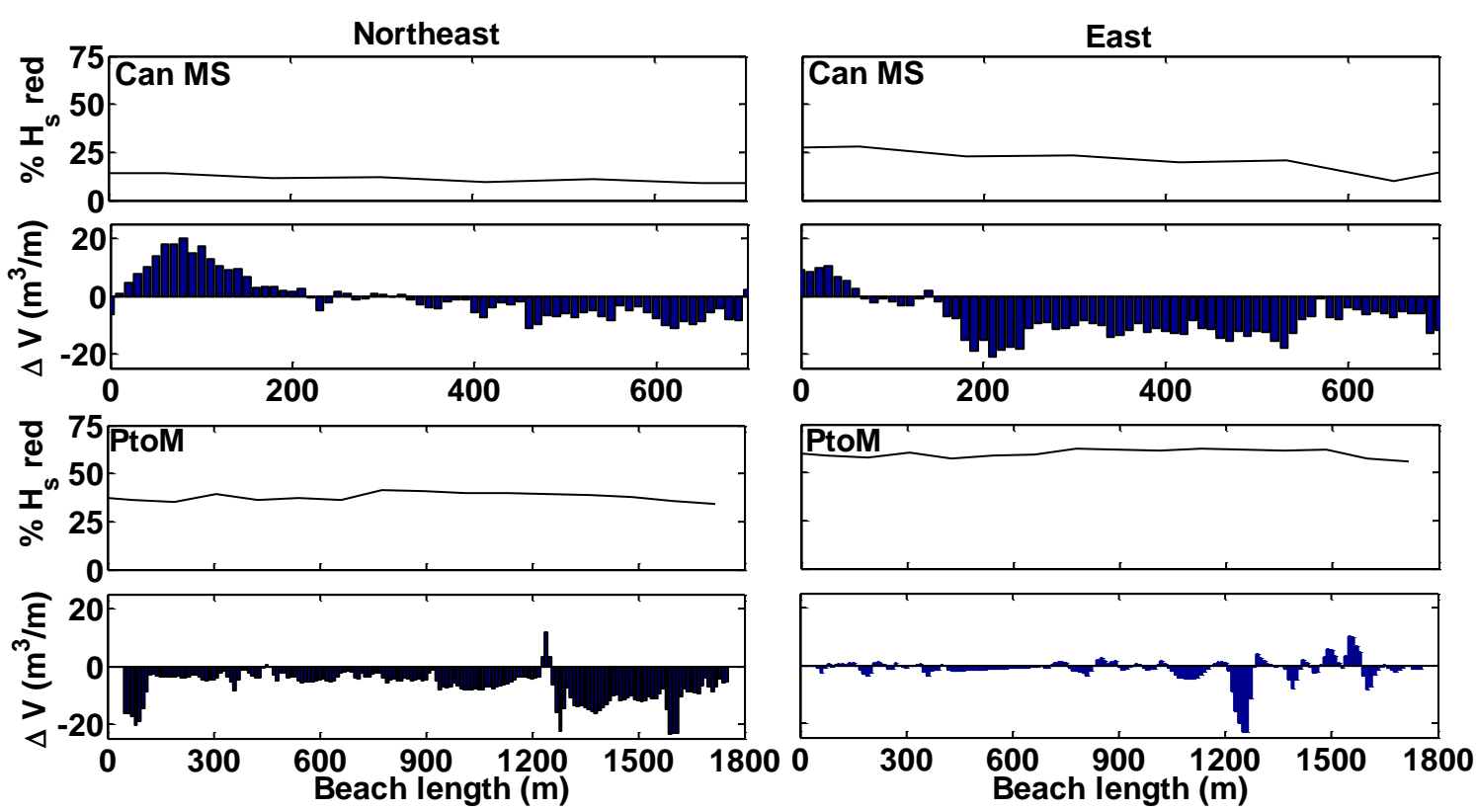

Figure 8. Measured longshore volumetric differences $(\Delta V)$ and SWAN simulated significant wave height reductions (in \%) between intermediate $(12 \mathrm{~m}$ ) and shallow $(3 \mathrm{~m})$ waters along Mid-South Cancun and Puerto Morelos for the main wave directions: northeast (left) and east (right). Boundary conditions consist of $\mathrm{H}_{\mathrm{s}}=3$ $\mathrm{m}$ and $\mathrm{T}=7 \mathrm{~s}$.

\section{CONCLUSIONS}

The morphological response of two adjacent beaches exposed to the same offshore wave climate was compared in the Mexican Caribbean coast based on topographic field data, where one of the beaches is fringed by a coral reef (Puerto Morelos) and the other is not (Cancun). In addition, the degree of energy dissipation provided by the fringing reef was evaluated applying the calibrated SWAN wave model and using a spatially uniform wave hydraulic roughness length scale, $\mathrm{k}_{\mathrm{w}}$, of $0.1 \mathrm{~m}$.

The obtained results demonstrate that under shore-normal wave conditions Puerto Morelos, which is fringed by a coral reef, was the more stable beach section. Further numerical experiments will be undertaken to determine the influence of the reef crest height and the distance of the reef to the shore in the amount of wave energy dissipation.

\section{ACKNOWLEDGEMENTS}

The field campaigns were funded by the Mexican Science Agency CONACYT-FOMIX (QROO2003-C02-12707) and CINVESTAV internal budget. Amaia Ruiz de Alegría-Arzaburu gratefully acknowledges the support provided by the Universidad Nacional Autónoma de México (UNAM) during her postdoctoral period through the CJIC/CTIC/2290/2010 scholarship. The authors are very grateful to all beach assistants from CINVESTAV in Mérida, especially Emanuel Uc Sanchez for his technical support. Thanks are also given to the Coral Reef Unit (ICMyL, UNAM) for the logistic support provided at the site through Edgar Escalante Mancera and Francisco Ruiz Rentería. 


\section{REFERENCES}

Alvarez-Filip, L., Dulvy, N. K., Gill, J.A., Cote, I.M., Watkinson, A.R. 2009. Flattening of Caribbean coral reefs: region-wide declines in architectural complexity. Proceedings of the Royal Society B: Biological Sciences 276, 3019-3025.

Alvarez-Filip, L., Cote, I.M., Gill, J.A., Watkinson, A.R., Dulvy, N. K. 2011. Region-wide temporal and spatial variation in Caribbean reef architecture: is coral cover the whole story? Global Change Biology. doi: 10.1111/j.1365-2486.2010.02385.x

Booij, N., Ris, R. C., Holthuijsen, L. H. 1999. A third-generation wave model for coastal regions. 1. Model description and validation. Journal of Geophysical Research 104, 7649-7666.

Coronado, C., Candela, J., Iglesias-Prieto, R., Sheinbaum, J., Lopez, M., Ocampo-Torres, F.J. 2007. On the circulation in the Puerto Morelos fringing reef lagoon. Coral Reefs 26, 149-163.

Gardner, T. A., Cote, I. M., Gill, J. A., Grant, A., Watkinson, A. R. 2003. Long-term region-wide declines in Caribbean corals. Science 301, 958-960.

Hearn, C.J. 1999. Wave-breaking hydrodynamics within coral reef systems and the effect of changing relative sea level. Journal of Geophysical Research, Series C 104, 30007-30019.

Hoeke, R., Storlazzi, C., Ridd, P. 2011. Hydrodynamics of a bathymetrically complex fringing coral reef embayment: Wave climate, in situ observations, and wave predictions. Journal of Geophysical Research, 116, C04018, doi:10.1029/2010JC006170.

Kench, P.S., Brander, R.W., Parnell, K.E., O’Callaghan, J.M. 2009. Seasonal variations in wave characteristics around a coral reef island, South Maalhosmadulu atoll, Maldives. Marine Geology 262, 116-129.

Lowe, R. J., Falter, J. L., Bandet, M. D., Pawlak, G., Atkinson, M. J., Monismith, S. G., Koseff J. R. 2005. Spectral wave dissipation over a barrier reef. Journal of Geophysical Research 110, C04001, doi: 10.1029/2004JC002711.

Lowe, R. J., Falter, J. L., Monismith, S. G., Atkinson M. J. 2009. A numerical study of circulation in a coastal reef-lagoon system. Journal of Geophysical Research 114, C06022, doi: 10.1029/2008JC005081.

Sanderson, P.G. 2000. A comparison of reef-protected environments in Western Australia: the central west and Ningaloo coasts. Earth Surface Processes and Landforms 25, 397-419.

Sheppard, C., Dixon, D.J., Gourlay, M., Sheppard, A., Payet, R. 2005. Coral mortality increases wave energy reaching shores protected by reef flats: Examples from the Seychelles. Estuarine Coastal and Shelf Science 64, 223-234.

Storlazzi, C. D., Elias, E., Field, M. E., Presto, M. K. 2011. Numerical modeling of the impact of sealevel rise on fringing coral reef hydrodynamics and sediment transport. Coral Reefs 30, 83-96 doi:10.1007/s00338-011-0723-9.

Zawada, D.G., Piniak, G.A., Hearn, C.J. 2010. Topographic complexity and roughness of a tropical benthic seascape. Geophysical Research Letters 37, L14604, doi:10.1029/2010GL043789 